Crop Breeding and Applied Biotechnology 10: 305-311, 2010

Brazilian Society of Plant Breeding. Printed in Brazil

\title{
Genetic control of agronomic traits in an oat population of recombinant lines
}

\author{
Itamar Cristiano Nava $^{1 *}$, Ismael Tiago de Lima Duarte ${ }^{2}$, Marcelo Teixeira Pacheco ${ }^{2}$ and Luiz Carlos Federizzi ${ }^{2}$
}

Received 18 January 2010

Accepted 30 April 2010

\begin{abstract}
Understanding the genetic control of phenotypic traits is essential to increase the efficiency of selection for adapted, high-yielding genotypes. The purpose of this study was to determine the genetic control of nine traits of hexaploid oat. Phenotypic data were collected from a population of 162 recombinant lines derived from the cross 'UFRGS17 $x$ UFRGS 930598-6'. For the traits plant growth habit, hairs on leaf edges and panicle type, monogenic genetic control was observed. A quantitative and/or polygenic genetic control was stated for the traits panicle weight, panicle length, vegetative cycle, plant height, test weight and grain yield. High heritability was estimated for the traits vegetative cycle $\left(h^{2}=0.89\right)$ and plant height $\left(h^{2}=0.79\right)$, while moderate heritability was determined for test weight $\left(h^{2}=0.51\right)$ and grain yield $\left(h^{2}=0.48\right)$.
\end{abstract}

Key words: heritability, grain yield, plant height, quantitative traits.

\section{INTRODUCTION}

Oat is an important cereal grown in different regions of the world. Cultivation is most widespread and concentrated in temperate and humid climate zones in North America and Europe (Murphy and Hoffman 1992). In Latin America, Brazil is a major producer of oat, where it is grown in the winter and plays an important role in grain production in crop rotation, such as soybeans. Most cultivated varieties of oat belong to Avena sativa $\mathrm{L}$., an allohexaploid species, with $2 n=6 x=42$ chromosomes, originated from the aggregation of three ancestral diploid genomes AA, CC, DD (Rines et al. 2006).

The development of modern farming practices, optimization of natural resources and the selection of superior genotypes with desirable agronomic traits have increased cereal yields in recent decades. The increase in oat grain yield as a result of genetic improvement ranged from zero to $0.8 \%$ per year, depending on the site and the genotypes for the different evaluation periods (Holland 1997). Many economically important traits in recently released oat cultivars have been improved, e.g., greater lodging resistance, higher harvest index and lower seed coat content. However, the genetic gains in oat are lower than for other cereal species such as wheat and barley, which can be attributed to the presence of undesirable traits in elite germplasm, such as disease susceptibility (Stuthman 1995).

A better understanding of the genetic control related to the phenotypic variation in morpho-physiological and qualitative-quantitative traits is seen as a fundamental step in breeding programs. This allows an improved efficiency

\footnotetext{
${ }^{1}$ Departamento de Agronomia, Universidade Estadual do Centro-Oeste, Rua Camargo Varela de Sá, 03, 85040-080, Guarapuava, PR, Brazil. *E-mail: inava@unicentro.br.

${ }^{2}$ Departamento de Plantas de Lavoura, Faculdade de Agronomia, Universidade Federal do Rio Grande do Sul, Avenida Bento Gonçalves, 7712, 91501-970, Porto Alegre, RS, Brazil.
} 
in the selection of well-adapted genotypes with high yield potential. Several studies investigated the genetic control of important oat traits, such as partial leaf rust resistance (Martinelli et al. 2009), photoperiod sensitivity and flowering (Locatelli et al. 2008), tolerance to aluminum toxicity (Oliveira et al. 2005, Nava et al. 2006), morphology of primary grain (Cabral et al. 2001), plant height (Mariot et al. 1999), and panicle type (Bertagnolli and Federizzi 1994).

Although the expression of some phenotypic traits in oat is controlled by one or a few loci of strong effect, most traits of economic importance are complex, multigenic and measured on a quantitative scale. Our objectives were to determine the genetic control of nine oat traits and estimate the heritability coefficient for the traits vegetative cycle, plant height, test weight and grain yield in a population of recombinant lines of hexaploid oat.

\section{MATERIAL AND METHODS}

The main mechanism of genetic control of nine traits in cultivated oat (Avena sativa L.) was analyzed in this study. Genetic analysis of a population of recombinant lines derived from crosses between the parental lines 'UFRGS 17' and 'UFRGS 930598-6' was performed and nine phenotypic traits were evaluated (Table 1). The parental lines UFRGS 17 and UFRGS 930598-6 were crossed in 1998. The population of recombinant lines was developed by the modified SSD method (Single Seed Descent), in which a panicle instead of one seed per plant was harvested. So from all $\mathrm{F}_{2}$ plants a panicle was removed which after threshing the grain was sown in single-hill plots in the following year in the $\mathrm{F}_{3}$ generation. One panicle was randomly collected from each single-hill plot which was threshed and sown in single-hill plots in generation $\mathrm{F}_{4}$. And so forth, until the $\mathrm{F}_{5}$ generation, where each panicle resulted in two paired 2-m rows that were bulk-harvested to form the recombinant lines used in this study.

Phenotypic data were collected in experiments at the agronomic experimental station (EEA) of the Federal University of Rio Grande do Sul (UFRGS), in the growing seasons of 2003 and 2004. The EEA is located in Eldorado do Sul, RS (lat $30^{\circ} 05^{\prime} 27^{\prime \prime} \mathrm{S}$, long $51^{\circ} 40^{\prime} 18^{\prime \prime} \mathrm{W}$ and mean altitude $46 \mathrm{~m}$ asl). The soil of the EEA was classified as a sandy clay loam Acrisol (Paleudult) (Embrapa 1999).

A population of 162 recombinant lines in the $F_{5: 7}$ generation was analyzed for the traits plant growth habit, hairs on leaf edges and panicle type, weight and length, in the 2003 growing season. These traits are some of the oat
Table 1. Morphological description of the parental lines UFRGS 17 and UFRGS 930598-6 for nine traits in the growing seasons of 2003 and 2004

\begin{tabular}{lcc}
\hline Trait & UFRGS 17 & UFRGS 930598-6 \\
\hline Growth habit & Intermediate (5) & Semi-prostrate (7) \\
Hairs on leaf edges & Present (1) & Absent (0) \\
Panicle type & Compact (2) & Loose (1) \\
Panicle weight (g) & $3.9 \pm 0.86$ & $2.8 \pm 0.72$ \\
Panicle length (cm) & $19.2 \pm 1.80$ & $20.1 \pm 1.40$ \\
Vegetative cycle (days) & $107 \pm 2.20$ & $112 \pm 1.05$ \\
Plant height (cm) & $105 \pm 3.90$ & $96 \pm 4.60$ \\
Test weight $(\mathrm{g})$ & $57.3 \pm 1.02$ & $56.2 \pm 0.72$ \\
Grain yield $\left(\mathrm{kg} \mathrm{ha}^{-1}\right)$ & $5.114 \pm 281.10$ & $4.293 \pm 326.20$ \\
\hline
\end{tabular}

\pm standard deviation (positive or negative) from the mean of the metric traits evaluated in the parental lines UFRGS 17 and UF RGS 930598-6.

descriptors used in the protection of plant varieties by the Serviço Nacional de Proteção de Cultivares. Recombinant lines and parental lines were planted in two $2 \mathrm{~m}$ long rows, spaced $0.2 \mathrm{~m}$ apart, without replications. Row spacing between different lines was $0.4 \mathrm{~m}$, sown at a density of 300 seeds per $\mathrm{m}^{2}$.

The trait plant growth habit was evaluated 45 days after emergence: semi-upright or semi-vertical (score 3), intermediate (score 5), semi-prostrate (score 7) and prostrate habit (score 9). The trait hairs on leaf edges was assessed when plants had six fully expanded leaves, by visual observation of absence (score 0 ) or presence (score 1) of hairs along the leaf edges. The trait panicle type was evaluated at physiological plant maturity, differentiated in loose panicle (score 1) and compact panicle (score 2). Panicle weight was determined by weighing 10 individual panicles collected randomly from each plot. The same panicles were assessed separately from the insertion point of the first node to the apex, to determine panicle length.

For the experiment of the 2004 growing season, the same recombinant lines described above were evaluated for vegetative cycle, plant height, test weight, and grain yield. Each line was sown mechanically in five 3-m rows, spaced $0.2 \mathrm{~m}$ apart, at a planting density of 300 seeds $\mathrm{m}^{-1}$ and evaluated in a complete block design with three replications. The growing cycle was measured by the number of days from sowing to flowering at stge $55^{\text {th }}$ on Zadoks growth scale (Zadoks et al. 1974). Height was measured in 10 plants after physiological maturity. Test weight was measured as the mass of kernels (awns clipped) that occupy a volume of $250 \mathrm{~mL}$, converted to the mass of a volume of 100 liters. The grain yield was composed by the 
total volume harvested from each plot and converted to $\mathrm{kg} \mathrm{ha}^{-1}$.

From the phenotypic data, genetic hypotheses regarding the number of genes involved in controlling the traits of plant growth habit, hairs on leaf edges and panicle type were formulated. The expected frequency for each trait was estimated from recombinant lines in the $F_{5: 7}$ generation, which had a low frequency of heterozygous loci. Lines segregating for the trait under study were not considered in genetic analysis. The deviations between the observed and expected frequencies for each trait were compared by the Chi-square $\left(\chi^{2}\right)$ test.

For traits with continuous phenotypic variation, such as panicle weight, panicle length, vegetative cycle, plant height, test weight and yield, genetic analysis was based on the frequency distribution of the mean value of each line for the trait under study. The definition of the class interval and the number of classes were determined according to Steel and Torrie (1980).

The data were tested by analysis of variance, using the F test at $1 \%$ probability. From the mean-square expectation $\mathrm{E}(\mathrm{MS})$ the components of total phenotypic variance (VP) were partitioned in genetic variance (VG) and environmental variance (VE). Thus, the heritability coefficient $\left(\mathrm{h}^{2}\right)$ was estimated for the traits vegetative cycle, plant height, test weight, and grain yield. Heritability estimates were based on the mean of recombinant lines evaluated at one location with three replications (r), according to the model described by Vencovsky (1973).

\section{RESULTSAND DISCUSSION}

The use of recombinant lines obtained by the SSD method for genetic analysis may be biased in the case of selection or the loss of a significant number of plants over generations. This was not the case in this study since in the number of plants lost from $F_{2}$ to $F_{5}$ was not significant. Genetic analysis of the trait growth habit in oat was performed in a population of 158 recombinant lines. The growth habit of the parental lines UFRGS 17 and UFRGS 930598-6 was intermediate (5) and semi-prostrate (7), respectively (Table 1). In 22 of the lines evaluated, the growth habit was semi-upright (3), in 52 intermediate (5), in 60 semi-prostrate (7) and in 24 prostrate (9) (Table 2). The results showed that the growth habit of $72 \%$ of the tested lines was similar to the parental lines ( 5 and 7 ), and that $28 \%$ exhibited a recombinant phenotype (3 and 9). The expected frequency for each phenotypic class was estimated based on the recombination frequency. Thus, it is expected that the growth habit of $14 \%$ of the lines is semi-upright (3), 36\% intermediate (5), 36\% semiprostrate (7) and $14 \%$ prostrate (9). From the observed and expected frequencies for plant growth habit in oat, the genetic hypothesis of two linked genes was tested. The chi-square test $\left(\chi^{2}=0.6584, P=0.8829\right)$ demonstrated that the difference between the observed and expected frequencies was not significant, supporting the hypothesis of two linked genes (Table 2). The results showed that the frequency of the parental lines represented in this model by the genotypes $A A b b$ (UFRGS 17) and $a a B B$ (UFRGS 930598-6) was higher than of the recombinant genotypes $A A B B$ and $a a b b$, with the distribution typical of linked genes (Table 2). The upright or semi-vertical growth habit $(A A B B)$ has been incorporated in most commercially released modern oat cultivars. In general, the plant growth habit is upright or semi-vertical and

Table 2. Chi-square test $\left(\chi^{2}\right)$ of the observed and expected phenotypic ratios in the model of two linked genes involved in the genetic control of growth habit trait in hexaploid oats

\begin{tabular}{|c|c|c|c|c|c|}
\hline \multirow[b]{2}{*}{ Lines } & \multicolumn{4}{|c|}{ Growth habit } & \multirow[b]{2}{*}{ Sum } \\
\hline & $\begin{array}{l}\text { Semi-vertical } \\
\text { (3) } A A B B\end{array}$ & $\begin{array}{c}\text { Intermediate } \\
\text { (5) } \boldsymbol{A} A \boldsymbol{A} b \boldsymbol{b}\end{array}$ & $\begin{array}{l}\text { Semi-prostate } \\
\text { (7) } a a B B\end{array}$ & $\begin{array}{c}\text { Prostrate (9) } \\
a a b b\end{array}$ & \\
\hline UFRGS 17 & & $100 \%$ & & & \\
\hline UFRGS 930598 & & & $100 \%$ & & \\
\hline Observed proportion (RILs ${ }^{a}$ ) & 22 & 52 & 60 & 24 & 158 \\
\hline Expected proportion (RILs ${ }^{\mathrm{a}}$ ) & 22 & 57 & 57 & 22 & 158 \\
\hline Gamete frequency $(\%)$ & 14 & 36 & 36 & 14 & 100 \\
\hline Chi-square test & & & & & $0.6584^{b}$ \\
\hline
\end{tabular}

${ }^{\mathrm{a}} \mathrm{RILs}=$ Recombinant Lines; ${ }^{\mathrm{b}}$ Calculated probability of $\chi^{2}=0.8829$. 
low height allows the band application of higher $\mathrm{N}$ doses without lodging and consequently higher grain yield (Kolchinski and Schuch 2003).

For the trait hairs on leaf edges, the phenotype of the parental lines UFRGS 17 and UFRGS 930598-6 is hairy (1) and non-hairy (0), respectively (Table 1 ). The 160 recombinant lines were evaluated, of which 135 lines were hairy (1) and 20 lines non-hairy (0) along the leaf edges (Table 3). Based on this classification, the genetic hypothesis of three genes controlling the trait was established. With three genes involved, a segregation ratio of 7:1 between the recombinant lines would be expected. The Chi-square test $\left(\chi^{2}=1.4286, P=0.2320\right)$ demonstrated that the difference between the observed and expected frequencies was not significant and the genetic hypothesis was accepted (Table 3). If the difference between the parental genotypes is three loci, eight different genotypes can be obtained in the recombinant lines for the trait hairs on leaf edges. The ratio of 7:1 indicates that only the recessive genotype for the three loci (e.g. aabbcc) is non-hairy. The presence of a dominant allele at any of the three loci makes the hairs appear on the leaf edges. Since the trait is recessive, once a non-hairy plant in any segregating generation is identified and selected, it will no longer segregate and the trait will be fixed.

The parental lines UFRGS 17 and UFRGS 930598-6 have compact (2) and loose panicles (1), respectively (Table 1). The trait panicle type was determined in a population of 158 lines, of which 84 lines had loose (1) and 74 lines compact panicles (2) (Table 4). With just one gene involved, a segregation ratio of 1:1 (loose: compact) between the homozygous lines was expected. The Chisquare test $\left(\chi^{2}=0.6328, P=0.4263\right)$ indicated that one gene is involved in the trait control of panicle type in oat

Table 3. Chi-square test $\left(\chi^{2}\right)$ of the observed and expected phenotypic ratios in the model of three genes involved in genetic control of the trait hairs on leaf edges in hexaploid oat

\begin{tabular}{lccc}
\hline \multirow{2}{*}{ Lines } & \multicolumn{2}{c}{ Hairs on leaf edges } & \\
\cline { 2 - 3 } & $\begin{array}{c}\text { Present (1) } \\
\boldsymbol{7}^{\boldsymbol{c}}\end{array}$ & $\begin{array}{c}\text { Absent (0) } \\
\mathbf{1}^{\boldsymbol{c}}\end{array}$ & \\
\hline UFRGS 17 & $100 \%$ & & \\
UFRGS 930598-6 & & $100 \%$ & \\
Observed proportion (RILs ${ }^{\mathrm{a}}$ ) & 135 & 25 & 160 \\
Expected proportion (RILs ${ }^{\mathrm{a}}$ ) & 140 & 20 & 160 \\
\hline Chi-square test & & & $1.4286^{\mathrm{b}}$ \\
\hline
\end{tabular}

${ }^{\mathrm{a}} \mathrm{RILs}=$ Recombinant Lines; ${ }^{\mathrm{b}}$ Calculated probability of $\mathrm{c}^{2}=0.2320$.

'Genotypes of each class : 7 (AAbbcc, aaBBcc, aabbCC, AABBcc, AAbbCC, aaBBCC, AABBCC): 1 aabbcc.
(Table 4). One major gene controlling this trait and related to the gene responsible for height reduction in oat was shown by Federizzi and Qualset (1989) and Bertagnoli and Federizzi (1994). However, no linkage between the genes responsible for compact panicle and short plant height was observed in this study, since the parental lines UFRGS17 and UFRGS 930598-6 represent recombinant plants. Thus, the population of lines developed from this cross segregated independently for the trait panicle type. The occurrence of recombinant plants with the phenotypes loose panicles/short stature and compact panicle/high stature was also observed by Marshall and Murphy (1981) and Federizzi and Qualset (1989).

The trait control of growth habit, hairs on leaf edges and panicle type were monogenic or oligogenic; one or a few independent or linked genes are responsible for their expression. The genetic control of these traits allows the selection of plants with the desired phenotype within populations or segregating families from $\mathrm{F}_{2}$ onwards. Moreover, these traits are important for the experiments of distinctness, uniformity and stability - DUS, underlying the application for cultivar protection by the Serviço Nacional de Proteção de Cultivares (SNPC) of the Ministério da Agricultura.

In contrast to the traits described above, where the studied lines were grouped in few clearly distinguishable classes with Mendelian segregation proportions, the traits panicle weight, panicle length, vegetative cycle, plant height, test weight and grain yield varied continuously in a large number of intermediate and also recombinant classes, better and worse than the parental genotypes (Figure 1). Small phenotypic differences were observed between lines, with a nearly normal frequency distribution. The results of this study show a frequency distribution pattern of quantitative and possibly polygenic genetic control, in

Table 4. Chi-square test $\left(\chi^{2}\right)$ of the observed and expected phenotypic ratios in the model of one gene involved in the genetic control of the trait panicle type in hexaploid oat

\begin{tabular}{lccc}
\hline \multirow{2}{*}{ Lines } & \multicolumn{2}{c}{ Panicle } & \\
\cline { 2 - 3 } & $\begin{array}{c}\text { Loose (1) } \\
\text { aa }\end{array}$ & $\begin{array}{c}\text { Compact (2) } \\
\text { AA }\end{array}$ & \\
\hline UFRGS 17 & & & \\
UFRGS 930598-6 & $100 \%$ & $100 \%$ & \\
Observed proportion (RILs $)$ & 84 & 74 & 158 \\
Expected proportion (RILs $)$ & 79 & 79 & 158 \\
\hline Chi-square test & & & $0.6328^{\mathrm{b}}$ \\
\hline
\end{tabular}

${ }^{\mathrm{a}} \mathrm{RILs}=$ Recombinant Lines; ${ }^{\mathrm{b}}$ Calculated probability of $\chi^{2}=0.4263$. 

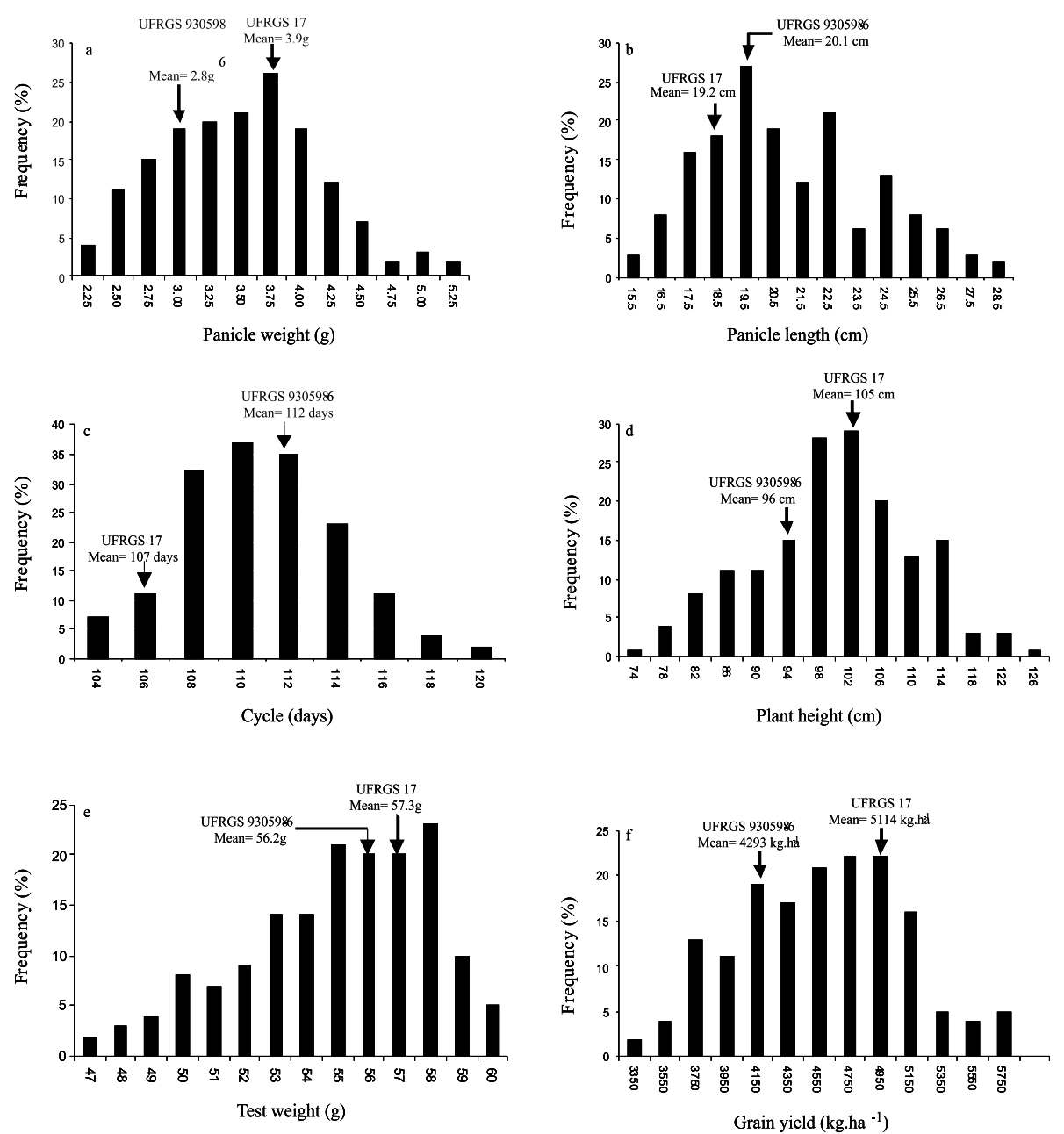

Figure 1. Frequency distribution of six morphometric traits assessed in an oat population of recombinant lines derived from cross UFRGS 17 x UFRGS 930598-6.

which a large number of genes with small effect on the phenotype must be involved. These results also show that the system to obtain recombinant lines used in this study effectively maintained the variability for most traits.

Variance analysis also indicated significant differences between the recombinant lines for the traits vegetative cycle, plant height, test weight, and grain yield (Table 5). The phenotypic variation observed can be attributed to genetic differences between the lines (inheritable component) and environmental differences (non-inheritable component). High heritability was estimated for the traits vegetative cycle $\left(h^{2}=0.89\right)$ and plant height $\left(h^{2}=0.79\right)$, while moderate heritability was estimated for the traits test weight $\left(h^{2}=0.51\right)$ and grain yield $\left(h^{2}=0.48\right)$ (Table 5). These results indicated that for vegetative cycle
Table 5. Analysis of variance, partitioning of total phenotypic variance in genetic and environmental components and heritability estimates for four traits of hexaploid oat

\begin{tabular}{lccc}
\hline Sources of variation & Df & MS & E(MS) \\
\hline Replication $(\mathrm{r})$ & $(\mathrm{r}-1)$ & MSr & $\sigma_{\mathrm{e}}^{2}+\mathrm{g} \sigma_{\mathrm{r}}^{2}$ \\
Genotype $(\mathrm{g})$ & $(\mathrm{g}-1)$ & $\mathrm{MSg}$ & $\sigma_{\mathrm{e}}^{2}+\mathrm{r}_{\mathrm{g}}^{2}$ \\
Error $(\mathrm{e})$ & $(\mathrm{g}-1)(\mathrm{r}-1)$ & Mse & $\sigma_{\mathrm{e}}^{2}$ \\
\hline Variable & $\mathbf{M S}$ & $\mathbf{F}$ test (genotype) & $\mathbf{C V ~ ( \% )}$ \\
\hline Plant height & 320.08 & $12.09^{* *}$ & 5.13 \\
Vegetative cycle & 35.13 & $26.59^{* *}$ & 1.03 \\
Grain yield & 866149.8 & $3.73^{* *}$ & 10.57 \\
Test weight & 29.66 & $4.09^{* *}$ & 4.90 \\
\hline Variable & $\mathbf{V G}$ & $\mathbf{V E}$ & $\mathbf{h}^{2}$ \\
\hline Plant height & 97.87 & 26.48 & 0.79 \\
Vegetative cycle & 11.27 & 1.32 & 0.89 \\
Grain yield & 211329.6 & 232161 & 0.48 \\
Test weight & 7.47 & 7.25 & 0.51 \\
\hline
\end{tabular}

** significant at $1 \%$ probability; $\mathrm{E}(\mathrm{MS})=$ mean square expectation; $\mathrm{VG}=$ genetic variance; $V E=$ environmental variance; $h^{2}=$ mean heritability. 


\title{
Controle genético de caracteres agronômicos em uma população de linhagens recombinantes de aveia
}

\begin{abstract}
RESUMO - O entendimento do controle genético de caracteres fenotípicos é fundamental para aumentar a eficiência de seleção de genótipos adaptados e com elevado potencial de rendimento. Os objetivos deste trabalho foram determinar o controle genético de nove caracteres de aveia hexaplóide. Observações fenotípicas foram coletadas em uma população de 162 linhagens recombinantes derivadas do cruzamento 'UFRGS17 x UFRGS 930598-6'. Os caracteres hábito de crescimento vegetativo, pilosidade na borda das folhas e tipo de panícula, apresentam controle genético monogênico. Controle genético quantitativo elou poligênico foi determinado para os caracteres peso de panícula, comprimento de panícula, ciclo vegetativo, estatura de plantas, peso do hectolitro e rendimento de grãos. Alta herdabilidade foi estimada para os caracteres ciclo vegetativo $\left(h^{2}=0,89\right)$ e estatura de plantas $\left(h^{2}=0,79\right)$, enquanto que herdabilidade moderada foi determinada para os caracteres peso do hectolitro $\left(h^{2}=0,51\right)$ e rendimento de grãos $\left(h^{2}=0,48\right)$.
\end{abstract}

Palavras-chave: herdabilidade, rendimento de grãos, estatura de planta, caracteres quantitativos.

and plant height, a greater proportion of phenotypic variation can be attributed to genetic variation, while test weight and yield are more influenced by environmental variation. Although heritability is an intrinsic measure of the trait and values vary in different populations, locations and years, this estimate is very useful in breeding, for indicating the response that can be expected in artificial selection (Carvalho et al. 2002). Moreover, environmental variation is partially controllable, since breeders can minimize environmental effects on the trait expression and decrease the genotype - environment interaction in the selection of superior plants. Greater uniformity among replications and experimental units decreases the experimental error and allows a clearer isolation of genetic from environmental effects, increasing the expected genetic gain due to higher selection efficiency.

\section{ACKNOWLEDGEMENTS}

The authors thank the Conselho Nacional de Desenvolviment Científico e Tecnológico (CNPq) for the financial support of this research and for the scholarship of the first author.

\section{REFERENCES}

Bertagnolli PF and Federizzi LC (1994) Genética do tipo de panícula em aveia (Avena sativa L.). Pesquisa Agropecuária Brasileira 29: 1237-1242.

Cabral CB, Milach SC, Pacheco MT and Crancio LA (2001) Herança de caracteres morfológicos de grãos primários em aveia. Pesquisa Agropecuária Brasileira 36: 1133-1143.

Carvalho FIF, Silva SA, Kurek A and Marchioro VS (2002) Estimativas e implicações da herdabilidade como estratégia de seleção. Editora UFPel, Pelotas, 107p.
Embrapa, Centro Nacional de Pesquisa de Solos (1999) Sistema brasileiro de classificação de solos. Embrapa Produção da Informação, Brasília, 412p.

Federizzi LC and Qualset CO (1989) Genetics of plant height reduction and panicle type in oat. Crop Science 29: 551-557.

Holland JB (1997) Oat improvement. In Kang MS (ed) Crop improvement for the $\mathbf{2 1}^{\text {st }}$ century. Research Signpost, Trivandrum, p. 57-98.

Kolchinski EM and Schuch LOB (2003) Eficiência no uso do nitrogênio por cultivares de aveia branca de acordo com a adubação nitrogenada. Revista Brasileira de Ciência do Solo 27: 1033-1038.

Locatelli AB, Federizzi LC, Milach SCK and McElroy AR (2008) Flowering time in oat: genotype characterization for photoperiod and vernalization response. Field Crops Research 106: 242-247.

Mariot MP, Sereno MJCM, Federizzi LC and Carvalho FIF (1999) Herança da estatura de planta e do comprimento da panícula principal no cruzamento entre Avena sativa L. e Avena sterilis. Pesquisa Agropecuária Brasileira 34: 77-82.

Marshall HG and Murphy CF (1981) Inheritance of dwarfness in three oat crosses and relationship of height to panicle and culm length. Crop Science 21: 335-338.

Martinelli JA, Chaves MS, Federizzi LC and Salvi V (2009) Expressão da resistência parcial à ferrugem da folha da aveia presente na linhagem MN841801, no ambiente do Sul do Brasil. Ciência Rural 39: 1335-1342.

Murphy JP and Hoffman LA (1992) Origin, history and production of oat. In Marshall HG and Sorrels ME (Eds.) Oat science and technology. Crop Science Society of American, Madison, p. 1-28.

Nava IC, Delatorre CA, Duarte ITL, Pacheco MT and Federizzi LC (2006) Inheritance of aluminum tolerance and its effects on grain yield and grain quality in oats (Avena sativa L.). Euphytica 148: 353-358. 
Oliveira PH, Federizzi LC, Milach SCK, Gotuzzo CC and Sawasato JT (2005) Inheritance in oat (Avena sativa L.) of tolerance to soil aluminum toxicity. Crop Breeding and Applied Biotechnology 5: 301-308.

Rines HW, Molnar SJ, Tinker NA and Phillips RL (2006) Oat. In Chittaranjan Kole (Ed.) Cereals and millets: genome mapping and molecular breeding in plants. Springer Berlin Heidelberg, New York, p.211-242.
Steel RGD and Torrie JH (1980) Principles and procedures of statistics. McGraw-Hill, New York, 633p.

Stuthman DD (1995) Oat breeding and genetics. In Welch RW (ed.) The oat crop: production and utilization. Chapman and Hall, London, p.150-176.

Vencovsky R (1973) Princípios de genética quantitativa. Instituto de Genética, Piracicaba, 97p.

Zadoks JC, Chang TT and Zonzak CF (1974) A decimal code for the growth stages of cereals. Weed Research 14: 415-421. 